$1(28) / 2015$

\author{
Roman Dolata \\ Uniwersytet Warszawski \\ dolata58@gmail.com
}

\title{
Na marginesie artykułu Hipoteza - krzywa wiedzy dziecka
}

Zamieszczony w ostatnim numerze „Problemów Wczesnej Edukacji” z 2014 roku tekst Hipoteza - krzywa wiedzy dziecka, autorstwa Kamila Stępnia i Bogdana Stępnia ${ }^{1}$, dotyczy ważnego problemu teoretycznego o znaczących implikacjach praktycznych: jaki jest związek biologicznego wieku rozpoczęcia nauki szkolnej z osiągnięciami szkolnymi na zakończenie szkoły podstawowej? Dodatkowym walorem tekstu jest jego polemiczny charakter, ponieważ autorzy krytykują wyniki uzyskane przez innych badaczy, którzy wcześniej podjęli ten sam temat. Krytyka naukowa jest najważniejszym mechanizmem rozwoju wiedzy i warto ją pielęgnować. Dobrze uzasadniona, powinna skrytykowanych zmotywować do doskonalenia warsztatu, jednak nieuzasadniona-musi spotkać się z równie krytyczną repliką.

1. W opisie problemu badawczego K. Stępień i B. Stępień przywołują tekst referatu A. Pokropka i autora niniejszej repliki, zatytułowany: Czy warto urodzić się w styczniu? Wpływ wieku biologicznego na wyniki egzaminacyjne. Reasumując wyniki przedstawionych przez nas analiz piszą:

Autorzy ci prognozuja, że obniżenie WOS (wieku obowiazku szkolnego) z 7 do 6 lat spowoduje spadek wiedzy absolwentów szkót podstawowych o 2,5,3\% w skali standardowej 100/15 i przyjmuja, że spadek tej wiedzy jest funkcja liniowa wieku dziecka. Z przedstawionych przez nich wykresów 3, 4 i 5 oraz ich obserwacji, że różnice pomiędzy średnimi wynikami uczniów urodzonych $w$ styczniu i grudniu z egzaminu gimnazjalnego sq niższe, niż ze sprawdzianu po 6-klasie - wynika jednak (podk. RD), że wiedza dzieci jest funkcja nieliniowa w zmiennej ich wieku.

Nie jest to trafne streszczenie naszych tez. Pozwolę sobie przytoczyć je w oryginale. Przedstawiając dotychczasowy stan wiedzy w tego typu badaniach na świecie stwierdziliśmy, że:

Gdy nabór do szkoty obejmuje grupę uczniów (...) zróżnicowana ze względu na wiek biologiczny w zakresie 12 miesięcy, obserwujemy znaczaca statystycznie korelację między wiekiem a osiagnięciami szkolnymi. Siła tej korelacji spada w kolejnych latach nauki szkolnej."

1 K., B. Stępień, Hipoteza - krzywa wiedzy dziecka. „Problemy Wczesnej Edukacji” 4(27)/2014, s. 63 73. 
W podsumowaniu napisaliśmy:

Wyniki analizy potwierdzaja istnienie zależności między wiekiem a osiagnięciami szkolnymi. Istnieje znaczaca statystycznie, ale niezbyt silna, stabnaca w czasie korelacja.

Jak widać, celem teoretycznym analiz nie była prognoza spadku wiedzy absolwentów szkoły podstawowej po obniżeniu wieku szkolnego, a model liniowy związku wieku z wynikami egzaminacyjnymi przyjmowaliśmy tylko dla analiz w obrębie danej kohorty. W podsumowaniu piszemy natomiast o prawdopodobnych skutkach praktycznych zwiększenia zróżnicowania wiekowego populacji szkolnych w tych latach, gdy do szkoły idą zarówno sześcio- jak i siedmiolatki:

Czego należy zatem oczekiwać, gdy do wieku egzaminacyjnego dorosna kohorty szkolne bardziej zróżnicowane wiekowo? Trudno o jednoznaczna prognozę. Gdyby doszto do losowego mieszania się w klasie I dzieci 6 i 7 letnich nalezatoby oczekiwać dwukrotnego wzrostu różnic między najstarszymi a najmłodszymi uczniami na sprawdzianie i egzaminie gimnazjalnym. Na sprawdzanie oznaczałoby to różnice dochodzące do 6 punktów w skali standardowej 100/15. Na egzaminie gimnazjalnym różnice wzrostyby do 2-3 punktów.

Po co zatem Autorzy artykułu Hipoteza - krzywa wiedzy dziecka w przeinaczają nasz referat? Jest to tym ważniejsze pytanie, że pozorna polemika z naszym tekstem pełni w tekście funkcję zaplecza teoretycznego. Na marginesie warto zwrócić uwagę, że wyników na skalach standardowych nie wyrażamy w procentach.

2. W opisie problemu badawczego znajdujemy w omawianym tekście również następujący fragment:

Zespót Szkolnych Uwarunkowań Efektów Kształcenia IBE zbadat wyniki Testu Umiejętności Na Starcie Szkolnym przeprowadzonych na sześcio- i siedmiolatkach, które poszły do szkoły 1 września 2012 r. Test wykonano dwuetapowo: pierwsze badanie wykonano w ostatnim kwartale 2012 r., a drugie w drugim kwartale 2013 r. Wyniki badań tego Zespotu (SUEK IBE 2013) sugeruja, że obniżenie WOS do 6 lat nie wptynie na zmianę wyników uczniów ze sprawdzianu.

Najpierw sprostowanie. Jako opiekun naukowy zespołu SUEK brałem udział w projektowaniu przywołanego badania, ale raport badawczy powstał w Zespole Wczesnej Edukacji IBE (patrz: Kaczan, Rycielski 2014). Oczywiście sprostowanie to nie jest zarzutem wobec Autorów, bo skąd mieliby o tym wiedzieć, skoro notka prasowa, która pojawiła się na stronie IBE po prezentacji wyników tego badania faktycznie zawierała taką mylną informację. Chodzi natomiast o uzyskane w tym badaniu wyniki, które w żadnym razie nie sugerują, że obniżenie wieku szkolnego nie wpłynie na zmianę wyników na sprawdzianie. W wielkim skrócie najważniejsze wyniki badania to stwierdzenie, że: 
(1) sześciolatki, które trafiły do I klasy, miały na starcie w porównaniu z tymi, które trafiły do „zerówek” szkolnych i przedszkolnych, znacznie wyższy poziom umiejętności typu szkolnego,

(2) sześciolatki, które trafiły do I klasy, zrobiły w trakcie pierwszego roku nauki znaczący postęp, porównywalny z dziećmi siedmioletnimi,

(3) postęp, jaki zrobiły w zakresie umiejętności typu szkolnego sześciolatki w zerówkach szkolnych i przedszkolnych był porównywalny z tym, który zrobiły te, które trafiły do I klasy,

(4) miary dobrostanu psychicznego i funkcjonowania społecznego sześciolatków nie wykazały w drugim pomiarze znaczących różnic między ścieżkami edukacyjnymi.

Który z tych wyników sugeruje brak wpływu obniżenia wieku szkolnego na wyniki sprawdzianu w klasie VI? Znów mam wrażenie, że brak teoretycznego zaplecza Autorzy „łatają” pozorną polemiką.

Oddzielną kwestią jest publiczna recepcja przywołanego tu badania przeprowadzonego przez IBE. Faktycznie enuncjacje prasowe po ogłoszeniu rezultatów zbyt często zawierały uproszczoną tezę, że sześciolatki na koniec I klasy mają umiejętności nie gorsze niż siedmiolatki, bez dodania, że chodzi o sześciolatki silnie wyselekcjonowane. Mylący mógł być również tytuł materiału prasowego przygotowanego przez IBE, ale już pierwszy wykres prezentujący wyniki wyraźnie pokazywał, o co chodzi. Ponieważ nie brałem udziału w opracowywaniu wyników tego badania, nie znam szczegółów wątku ,prasowego". Jako pracownik IBE muszę jednak stwierdzić, że sądząc po owocach, z pewnością w tym wypadku popełniliśmy błąd w komunikowaniu opinii publicznej wyników badań naukowych.

3. Sporą część wysiłku analitycznego Autorzy tekstu: Hipoteza - krzywa wiedzy dziecka, poświęcili opisowi dobrze znanego, corocznie dokumentowanego w raportach CKE, zróżnicowania parametrów rozkładu surowych wyników sprawdzianu w całości i z podziałem na obszary standardów egzaminacyjnych. Użycie w analizach wyników dla poszczególnych obszarów jest - bardzo delikatnie mówiąc - pomiarowo ryzykowane. Ich rzetelność i trafność jest bardzo niska (skale te czasami składają się z 2-4 zadań) i raczej nie zasługują na poważne traktowanie przez badacza.

4. Na koniec chciałbym skomentować wnioski końcowe sformułowane przez Autorów artykułu: Hipoteza - krzywa wiedzy dziecka. Pierwszy z nich brzmi:

Dzieci idace do szkoły $w$ roku, w którym osiagaja WOS uzyskuja tym gorsze wyniki ze sprawdzianu, im poszly młodsze do szkoły i proces ten jest nieliniowy - im młodsze dzieci tym silniejszy spadek ich wyników.

Pierwsza część tego twierdzenia jest wysoce prawdopodobna i zgodna z wynikami naszych analiz. Jednak teza druga nie ma dostatecznego potwierdzenia. Zaproponowany model opisujący nieliniowość zbyt ogólnie nazwany „krzywą wiedzy dziecka” (raczej jest 
to „krzywa opisująca związek poziomu wiedzy z wiekiem rozpoczynania nauki szkolnej”) nie jest uzasadniony przez Autorów teoretycznie i nie wykazano jego dobrego dopasowania do danych. Podana wartość $\mathrm{R}^{2}$, jak zresztą piszą sami Autorzy, nie ma żadnej mocy dowodowej. Test dotyczy tak wąskiego wycinka zmienności zmiennej niezależnej, że równie dobrze byłyby dopasowane krzywe prowadzące do kompletnie innych wniosków.

Drugi wniosek brzmi:

Im młodsze idzie dziecko do szkoty w roku, w którym osiaga WOS, tym większa ma ,,szansęe" na powtarzanie klasy i proces ten jest nieliniowy - im mlodsze dziecko, tym silniej wzrasta ta , szansa".

To bardzo ciekawe twierdzenie, zgodne zresztą (nie licząc nieliniowości) z wynikami w innych krajach. Autorzy jednak nie podają źródła, na którego podstawie stworzyli dowodzący tej zależności wykres. Jak sami zresztą piszą, w bazach egzaminacyjnych nie przechowuje się informacji o wieku rozpoczęciu nauki szkolnej. Skąd zatem zaczerpnięto te dane?

Trzeci, ostatni wniosek brzmi:

W oparciu o postawionq hipotezę - w powiqzaniu z analiza wyników siedmiolatków - prognozujemy, że obnizenie WOS do 6 lat, spowoduje spadek ogólnej wiedzy dzieci po 6-klasie szkót podstawowych okoto 7,3\%, największy spadek wystapi w umiejętności wykorzystania wiedzy w praktyce i wyniesie okoto $10 \%$.

Ponieważ hipoteza krzywej wiedzy nie została przekonująco zweryfikowana empirycznie, precyzyjne przewidywania obniżania poziomu wiedzy o rok młodszych absolwentów szkoły podstawowej są nieuzasadnione. Jest wysoce prawdopodobne, że obniżenie poziomu umiejętności wystąpi, ale ilościowe jego prognozowanie w dodatku z podziałem na obszary standardów wymagań - które zresztą w 2015 roku przechodzą do historii - to magia, a nie nauka.

\section{Przywolane teksty}

Dolata R., Pokropek A. (2012), Czy warto urodzić się w styczniu? Wplyw wieku biologicznego na wyniki egzaminacyjne. W: B. Niemierko, K. Szmigel (red.), Regionalne i lokalne diagnozy edukacyjne, Wrocław, PTDE.

Kaczan R., Rycielski (red.) (2014), Badanie 6- i 7-latków - rok szkolny 2012/13. Warszawa, Instytut Badań Edukacyjnych. 